\title{
EFFECTIVENESS OF PHYSICAL EXERCISE ON THE RECOVERY OF LIMB FUNCTION IN STROKE PATIENTS
}

\author{
EFICÁCIA DO EXERCÍCIO FÍSICO NA RECUPERAÇÃO DA FUNÇÃO DOS MEMBROS EM PACIENTES \\ COM AVC
}

Original Article

ARTIGO ORIGINAL

Artículo Original

\author{
EFECTIVIDAD DEL EJERCICIO FÍSICO EN LA RECUPERACIÓN DE LA FUNCIÓN DE LAS EXTREMIDADES \\ EN PACIENTES CONACV
}

\author{
Jisheng Wang ${ }^{1}$ \\ (Physical Education Professional) \\ 1. Science of Physical Culture and \\ Sports, ZhengZhou Vocational \\ University of information and \\ Technology, Zhengzhou, China.
}

\section{Correspondence:}

Science of Physical Culture and Sports, ZhengZhou Vocational University of information and Technology, Zhengzhou 450000, China.wjs721019@163.com

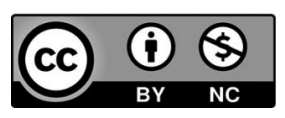

\begin{abstract}
Introduction: Patients with cerebrovascular accident and hemiplegia need to perform physical exercise and aerobic training, but physical dysfunction restricts the performance of these activities. Objective: The article aims to develop physical strength sports for stroke patients with hemiplegia to explore the efficacy of sports to regain limb function in these patients. Methods: We randomly selected 30 patients with stroke sequelae and divided them into control and exercise groups. While undergoing rehab, the exercise group performed a certain amount of aerobic exercise. During this period, we compared the relevant physiological indicators of the patients, and, at the same time, we used the Fugle-Meyer motor function scoring method to assess limb function. Results: The two groups of patients are significantly different regarding the recovery of physical function and the capacity for daily life. Physiological indicators of patients are also different. Conclusion: Low-intensity aerobic exercise can help stroke and hemiplegia patients regain their basic ability to live and exercise. Level of evidence Il; Therapeutic studies: investigation of treatment results.
\end{abstract}

Keywords: Stroke; Exercise; Effectiveness; Sports; Hemiplegia.

\section{RESUMO}

Introdução: É muito importante que pacientes com acidente vascular encefálico e hemiplegia realizem exercícios físicos e treinamento aeróbio, mas a disfunção física restringe a realização dessas atividades. Objetivo: o artigo tem como objetivo desenvolver esportes de força física para pacientes com AVC com hemiplegia para explorar a eficácia dos esportes para recuperar a função dos membros nesses pacientes. Métodos: Selecionamos aleatoriamente 30 pacientes com sequela de AVC e os dividimos em grupos controle e exercício. Durante a reabilitação, o grupo de exercícios realmente executou uma certa quantidade de exercícios aeróbicos. Durante esse período, comparamos os indicadores fisiológicos relevantes dos pacientes e, ao mesmo tempo, usamos o método de pontuação da função motora de Fugle-Meyer para avaliar a função dos membros. Resultados: Os dois grupos de pacientes são significativamente diferentes em termos de recuperação da função física e capacidade para a vida diária. Os indicadores fisiológicos dos pacientes também são diferentes. Conclusão: O exercício aeróbico de baixa intensidade pode ajudar os pacientes com derrame e hemiplegia a recuperar sua capacidade básica de viver e se exercitar. Nível de evidência ll; Estudos terapêuticos: investigação dos resultados do tratamento.

Descritores: Acidente Vascular Cerebral; Exercício Físico; Efetividade; Esportes; Hemiplegia.

\section{RESUMEN}

Introducción: Es muy importante para los pacientes con accidente cerebrovascular y hemiplejía realizar ejercicio físico y entrenamiento aeróbico, pero la disfunción física restringe la realización estas actividades.Objeto: El artículo tiene como objetivo desarrollar deportes de fuerza física para pacientes con accidente cerebrovascular con hemiplejía para explorar la eficacia de los deportes para recuperar la función de las extremidades de estos pacientes. Métodos: Seleccionamos aleatoriamente a 30 pacientes con secuelas por accidente cerebrovascular y los dividimos en grupos de control y de ejercicio. Mientras se sometía a rehabilitación, el grupo de ejercicio llegó a realizar una cierta cantidad de ejercicio aeróbico. Durante este período, comparamos los indicadores fisiológicos relevantes de los pacientes y, al mismo tiempo, utilizamos el método de puntuación de la función motora de Fugle-Meyer para evaluar la función de las extremidades. Resultados: Los dos grupos de pacientes son significativamente diferentes en cuanto a la recuperación de la función física y la capacidad para la vida diaria. Los indicadores fisiológicos de los pacientes también son diferentes. Conclusión: El ejercicio aeróbico de baja intensidad puede ayudar a los pacientes con accidente cerebrovascular y hemiplejía a recuperar su capacidad básica de vida y ejercicio. Nivel de evidencia II; Estudios terapéuticos: investigación de los resultados del tratamiento.

Descriptores: Accidente Cerebrovascular; Ejercicio Físico; Efectividad; Deportes; Hemiplejía. 


\section{INTRODUCTION}

Aerobic training for stroke patients with hemiplegia is significant, but limb motor dysfunction limits aerobic training completion. There are not many studies on aerobic training for patients with stroke and hemiplegia.' A few studies in this area are aimed at patients with better limb function and assisted walking ability, and the training method of treadmill walking is adopted. There are few studies on the feasibility and effectiveness of aerobic training for stroke and hemiplegic patients who cannot assist walking, and there are few reports in China ${ }^{2}$ Theoretically speaking, these patients have a worse motor function and significantly reduced activity volume, which means more aerobic endurance training. The purpose of this study was to observe the effectiveness of low-intensity treadmill aerobic training for stroke and hemiplegic patients without walking ability. ${ }^{3}$

\section{METHOD}

\section{General information}

The article selected 30 patients with stroke and hemiplegia admitted to the Department of Rehabilitation Medicine from February 2019 to March 2020. They have stable vital signs and cannot complete assisted and independent walking but can complete resistance treadmill training in a sitting position.

\section{REHABILITATION TREATMENT METHODS}

\section{Control group}

The control group received conventional rehabilitation treatment. Rehabilitation treatments based on nerve promotion techniques, sitting balance, standing and walking training are performed five times a week, and the treatment time is 4 hours a day (including exercise therapy 2 hours, occupational therapy 1-hour, physical factor therapy and acupuncture 1 hour), a total of 6 weeks. This research group's previous research confirmed that the routine rehabilitation training of stroke patients could not reach the intensity of aerobic endurance training, so it can be considered that the control group's rehabilitation training does not include aerobic training.

\section{Aerobic training group}

In addition to regular rehabilitation treatment, aerobic endurance training is performed three times a week. On the day of aerobic training, the training intensity of power cycling in conventional rehabilitation treatment to aerobic training requirements and the other training time and content remain unchanged. The Dash4000 ECG monitor monitored the patient's aerobic training in the first week. Carry out a treadmill exercise test before aerobic endurance training. According to the method previously determined by this research group, the treadmill exercise test was carried out, namely treadmill exercise. Combining the pre-test and the results of the previous research of this research group, the patients in the aerobic training group adopted the following methods for low-intensity aerobic training.

\section{OBSERVATION INDICATORS}

\section{Heart rate, ECG changes and blood pressure}

Observe the heart rate when the target intensity is reached during each training session in the first week when the target intensity is $15 \mathrm{~min}$, and when the target intensity is 30min, the changes of ECG on CM5 or CC5 lead, the blood pressure of the uninhibited upper limb brachial artery, and the average blood pressure and heart rate of the patient during target intensity training. ${ }^{4}$

\section{Limb function}

We use the simple Fugl-Meyer motor function score method (FMA) and Rivermead sports index for evaluation.

\section{ADL capabilities}

We use the Baahel Index (BI) for evaluation. The above indicators were evaluated by the same physician before and after treatment using a blind method.

\section{End of exercise test heart rate and tolerance time}

Record the patient's heart rate and tolerance time before and after exercise test termination. ${ }^{5}$ Laboratory examination: Before and after treatment, the patient will take venous blood to check fasting blood glucose, blood insulin, blood lipids, blood cholesterol, high-sensitivity c-reactive protein, the oral glucose tolerance test (OGTT) $2 \mathrm{~h}$ blood glucose and insulin, and follow the formula [HOMA-IR=fasting blood glucosexfasting insulin $\div$ 22.5] Calculate the homeostatic model insulin resistance index (HOMA-IR). The higher the value, the lower the insulin sensitivity. ${ }^{5}$

\section{MOTION SPECTRUM RECOMMENDATION ALGORITHM}

\section{The introduction of a cepstral method}

For the convenience of analysis, assuming that the blur length of the motion blur image is $L$ and the angle $\theta$ is 0 , then

$$
\mathrm{h}(\mathrm{x}, \mathrm{y})=\left\{\begin{array}{lc}
\frac{1}{L} & 0 \leq x \leq L-1 \\
0 & \text { ot her wi se }
\end{array}\right.
$$

Its discrete Fourier transform is

$$
H(u)=\frac{e^{\frac{-\pi_{j} L u}{N}} \sin \left(\frac{L u \pi}{N}\right)}{e^{\frac{-\pi_{j} u}{N}} L \sin \left(\frac{u \pi}{N}\right)} 0 \leq u \leq N-1
$$

From equation (2), we know that the two zeros closest to the origin are respectively $\frac{N}{L},-\frac{N}{L}$. When the noise effect is not considered, that is, $N(u, v)=0$ in equation (2), then we know from equation (2):

$$
G(u, v) \mid u= \pm \frac{N}{L}=0
$$

Therefore, black stripes will appear in the spectrum image, and the blur scale can be determined according to the width of the bright stripes passing the origin. ${ }^{6}$ Set the width of the bright stripes passing the origin as $W$, then there is

$$
W=\frac{2 N}{L}
$$

This method can quickly determine the fuzzy scale when there is no noise interference, but when there is noise,

$$
G(u, v) \mid u= \pm \frac{N}{L} \neq 0
$$

\section{Definition and nature of cepstrum}

According to different application backgrounds, the definition of cepstrum is different. The definition of cepstrum used in this article is as follows:

$$
c(x, y)=F^{-1}(1 n|C(u, v)|)
$$


Among them, $|C(u, v)|$ represents the amplitude spectrum of the Fourier transform of $c(x, y)$, and $c(x, y)$ represents the cepstrum corresponding to $c(x, y)$, which is recorded as:

$$
c(x, y)=(c(x, y))
$$

The following system identification algorithm is proposed: Step 1: Perform a two-dimensional Fourier transform on the blurred image $g(x, y)$ to obtain $G(u, v)$.

Step2: Take the amplitude spectrum $|G(u, v)|$ of $G(u, v)$. To ensure that $G(u, v)=0$ is meaningful, take the logarithm of equation (7) to get $G$

$$
d(u, v)=1 n(1+|G(u, v)|
$$

Step3: Obtain the cepstrum $\boldsymbol{d}(u, v)$ of the blurred image $g(x, v)$ by inverse Fourier.

Step4:We divide $g(x, v)$ into four parts of equal size and exchange them in the direction shown in Figure 1 so that the origin is moved from the upper left corner to the center position.

Step5: Based on property 2, determine the blur scale and blur direction.

\section{Statistical analysis}

The data obtained is represented by $(\bar{x} \pm s)$. We use SPSS version 13.0 software to complete all statistical analyses. ${ }^{7}$ The comparison of measurement data uses the paired t-test, and the comparison of count data uses the $\chi^{2}$ test. $P<0.05$ indicates that the difference is statistically significant.

\section{RESULTS}

In the aerobic training group, the exercise test's average termination heart rate was (121.34 \pm 21.2$)$ beats/min. The patients had no cardiovascular system symptoms, signs and abnormal ECG performance during aerobic training. Two patients suffered from knee joint pain on the hemiplegic side after cycling training. However, the amount of training can be completed, and the pain has not significantly affected his daily life and other training. ${ }^{8}$

After treatment, FMA, Rivermead exercise index, Bl, exercise test tolerance time, fasting insulin, OGTT $2 \mathrm{~h}$ blood glucose, HOMA-IR, and high-sensitivity C-reactive protein were significantly improved after treatment in the aerobic training group $(P<0.05)$. Other indicators There was no significant change before and after treatment $(P>0.05)$.

The FMA and BI of the control group were significantly improved after treatment $(P<0.05)$, and the other indexes had no significant changes before and after treatment $(P>0.05)$. After treatment, the FMA, Rivermead exercise index, Bl, exercise test tolerance time, fasting insulin, and OGTT $2 \mathrm{~h}$ blood glucose of the aerobic training group was significantly better than those of the control group $(P<0.05)$. There was no significant difference between the two groups after treatment for other indicators Significance $(P>0.05)$. It is shown in Table 1.

\section{DISCUSSION}

Aerobic training for stroke patients is of great significance, especially for patients with apparent limb dysfunction and no transferable walking ability, because stroke patients often have poor endurance. Three are common risk factors such as high blood pressure and hyperglycemia. After the stroke, hemiplegia is aggravated and cannot be resolved by conventional rehabilitation treatment, so patients must undergo aerobic training. However, the impairment of limb function limits the completion of aerobic training for patients. Our research group has been committed to the feasibility study of aerobic endurance training for this type of patient. Based on the pre-experiment results, we choose treadmill exercise as the aerobic training method because the patient's healthy lower extremity can drive the patient's lower extremity to complete particular training. Whether stroke patients can tolerate such training volume has become the main content of this research.

In response to the above problems, our research group conducted low-intensity aerobic exercises on stroke patients with hemiplegia without walking ability to observe aerobic training's feasibility and effectiveness for such patients. Results Except for one patient who induced pain in the hip joint on the hemiplegic side during cycling and was unable to adhere to the training, the rest insisted on completing all the training. ${ }^{9}$ The patient had no cardiovascular system symptoms and abnormal ECG performance under this training amount, indicating that he could not walk. Most severe stroke patients with hemiplegia can perform low-intensity aerobic training.

This study shows that low-intensity treadmill aerobic endurance training can improve patients' exercise function, exercise test tolerance time,

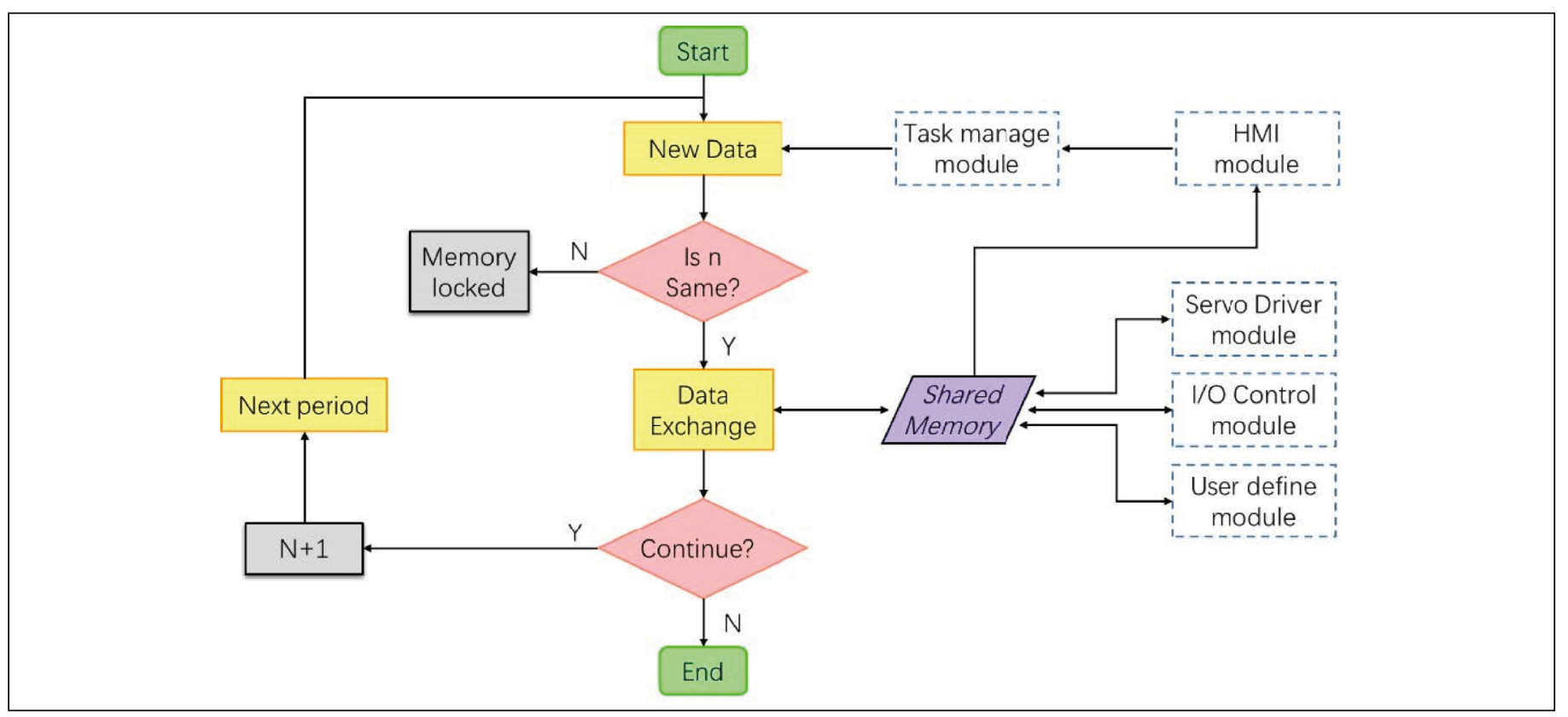

Figure 1. Schematic diagram of data exchange. 
Table 1. Comparison of related observation indexes before and after rehabilitation treatment in the two groups.

\begin{tabular}{|c|c|c|c|}
\hline & Group & FMA (points) & Rivermead Sports Index (points) \\
\hline \multirow[t]{2}{*}{ Control group } & before therapy & $31.41 \pm 10.7$ & $4.1 \pm 0.5$ \\
\hline & After treatment & $40.2 \pm 10.3$ & $5.1 \pm 0.9$ \\
\hline \multirow[t]{3}{*}{ Aerobic training group } & before therapy & $35.1 \pm 19.8$ & $4.2 \pm 0.8$ \\
\hline & After treatment & $53.1 \pm 10.5$ & $6.0 \pm 0.5$ \\
\hline & Group & Fasting insulin $(\mu \mathrm{L} / \mathrm{L})$ & 0GTT2h blood glucose (mmol/L) \\
\hline \multirow{2}{*}{ Control group } & before therapy & $8.4 \pm 3.4$ & $9.9 \pm 1.9$ \\
\hline & After treatment & $8.1 \pm 4.4$ & $9.3 \pm 2.0$ \\
\hline \multirow{3}{*}{ Aerobic training group } & before therapy & $8.5 \pm 4.0$ & $10.3 \pm 2.0$ \\
\hline & After treatment & $7.1 \pm 2.5$ & $8.3 \pm 2.2$ \\
\hline & Group & $\begin{array}{l}\text { Heart rate at the end of } \\
\text { exercise test (times } / \mathrm{mm} \text { ) }\end{array}$ & Exercise test tolerance time ( $\mathrm{min}$ ) \\
\hline \multirow{2}{*}{ Control group } & before therapy & $121.3 \pm 21.2$ & $11.2 \pm 3.7$ \\
\hline & After treatment & $125.2 \pm 14.2$ & $10.6 \pm 3.1$ \\
\hline \multirow{2}{*}{ Aerobic training group } & before therapy & $124.2 \pm 16.2$ & $10.3 \pm 1.3$ \\
\hline & After treatment & $123.3 \pm 12.8$ & $15.1 \pm 2.3$ \\
\hline & Group & Blood lipid (mmol/L) & Cholesterol (mmol/L) \\
\hline \multirow{2}{*}{ Control group } & before therapy & $1.5 \pm 0.7$ & $4.8 \pm 0.6$ \\
\hline & After treatment & $1.4 \pm 0.4$ & $4.5 \pm 0.6$ \\
\hline \multirow{2}{*}{ Aerobic training group } & before therapy & $1.6 \pm 0.3$ & $4.4 \pm 0.3$ \\
\hline & After treatment & $1.5 \pm 0.5$ & $4.3 \pm 0.3$ \\
\hline & Group & $\mathrm{Bl}$ (minutes) & Fasting blood glucose (mmol/L) \\
\hline \multirow{2}{*}{ Control group } & before therapy & $42.6 \pm 10.5$ & $5.04 \pm 0.42$ \\
\hline & After treatment & $62.1 \pm 10.9^{*}$ & $5.19 \pm 0.42$ \\
\hline \multirow{2}{*}{ Aerobic training group } & before therapy & $43.1 \pm 10.2$ & $5.26 \pm 0.43$ \\
\hline & After treatment & $71.3 \pm 12.4$ & $4.98 \pm 0.51$ \\
\hline & Group & HOMA-IR & High sensitivity C-reactive protein $(\mu \mathrm{L} / \mathrm{L})$ \\
\hline \multirow{2}{*}{ Control group } & before therapy & $1.4 \pm 1.0$ & $3.0 \pm 1.2$ \\
\hline & After treatment & $1.6 \pm 1.2$ & $2.5 \pm 0.5$ \\
\hline \multirow{2}{*}{ Aerobic training group } & before therapy & $1.6 \pm 1.1$ & $3.4 \pm 7.1$ \\
\hline & After treatment & $1.3 \pm 0.7$ & $2.0 \pm 1.0$ \\
\hline
\end{tabular}

insulin sensitivity, two h postprandial blood glucose, and high-sensitivity C-reactive protein levels, suggesting that low-intensity treadmill aerobic endurance can be adequate. It can improve stroke patients'endurance who cannot walk and the risk factors for recurrence of heart and brain diseases. Therefore, aerobic training for such patients is compelling. ${ }^{10}$

\section{CONCLUSION}

In the results of this study, aerobic training has different effects on different indicators. The lack of improvement in blood lipids and cholesterol may be related to the relatively short training time and the relatively more influencing factors of dual indicators. OGTT $2 \mathrm{~h}$ blood glucose, fasting insulin, and high-sensitivity $C$ reaction in the blood Protein, insulin sensitivity, and exercise test tolerance time may be related to the endurance exercise involving the large muscles of the lower extremities, which improves muscle metabolism, especially the peripheral effects of insulin sensitivity.

The author declare no potential conflict of interest related to this article

AUTHORS' CONTRIBUTIONS: The author made significant contributions to this manuscript. Jisheng Wang: writing and performing surgeries; data analysis and performing surgeries; article review and intellectual concept of the article.

\section{REFERENCES}

1. Sun Q, Cai J. Effects of 12-type guidance method combined with prokin balance training instrument on the balance function and walking ability of stroke patients with hemiplegia. MEDS Public Health and Preventive Medicine. 2021 [cited 2021 Jun 9];1(1): 1-7. Available from: https://www.clausiuspress. com/assets/default/article/2021/02/07/article_1612750603.pdf

2. Ravichandran H, Janakiraman B, Sundaram S, Fisseha B, Gebreyesus T, Yitayeh Gelaw A. Systematic review on effectiveness of shoulder taping in hemiplegia. JStroke Cerebrovasc Dis. 2019;28(6):1463-73.

3. Nam Y, Shim J, Kim SJ, Namkoong S. Effects of whole body vibration exercise combined with forced weight bearing on balance and gait in patients with stroke hemiplegia. RJPT. 2019;12(9): 4117-20.

4. Küçük EB, Küçük E, Kaydok E, Zor KR, Biçer GY. Dry eye in chronic stroke patients with hemiplegia: A cross-sectional study. Top Stroke Rehabil. 2020;27(8):630-5.

5. Eslamian F, Farhoudi M, Jahanjoo F, Sadeghi-Hokmabadi E, Darabi P. Electrical interferential current stimulation versus electrical acupuncture in management of hemiplegic shoulder pain and disability following ischemic stroke-a randomized clinical trial. Arch Physiother. 2020 Jan 10;10:2.
6. Díaz-Arribas MJ, Martín-Casas P, Cano-de-la-Cuerda R, Plaza-Manzano G. Effectiveness of the Bobath concept in the treatment of stroke: a systematic review. Disabil Rehabil. 2020;42(12):1636-49.

7. Cioroiu SG. Kinetherapy recovery of hemiplegic patients elderly. Bulletin of the Transilvania University of Brasov. Series IX, Sciences of Human Kinetics. 2020 [cited 2021 Jun 9];13(1):207-12. Available from: http://webbut.unitbv.ro/Bulletin/Series\%20IX/2020/BULETIN\%20I/27_Cioroiu.pdf

8. Lee DJ, Cho SH. Effect of aquatic exercise on gait in persons with chronic stroke: a meta-analysis study in Korea. Phys Ther Rehabil Sci. 2019;8(2): 112-23.

9. Karthikbabu S, Verheyden G. Relationship between trunk control, core muscle strength and balance confidence in community-dwelling patients with chronic stroke. Top Stroke Rehabil. 2021;28(2):88-95

10. Wang S, Chen X, Zhuang R, Yang Z, Jiang W, Wang T. Flexors activity of affected upper extremity in stroke patients during different standing conditions and their relationships with clinical scales: a cross-sectional study. Neurol Res. 2020;42(3):244-52. 